\title{
Stakeholders' Perceptions of Chinese Takeovers: The Case of Germany and Italy (Evidence from the National Press)
}

\author{
Katiuscia Vaccarini \\ University of Macerata, Italy \\ Michael Nippa \\ University of Bozen-Bolzano, Italy \\ Francesca Spigarelli \\ University of Macerata, Italy
}

Doi:10.19044/esj.2021.v17n5p1

Submitted: 01 December 2020

Accepted: 28 January 2021

Published: 28 February 2021
Copyright 2021 Author(s)

Under Creative Commons BY-NC-ND

4.0 OPEN ACCESS

Cite As:

Vaccarini K., Nippa M. \& Spigarelli F. (2021). Stakeholders' Perceptions of Chinese Takeovers: The Case of Germany and Italy (Evidence from the National Press).

European Scientific Journal, ESJ, 17(5), 1. https://doi.org/10.19044/esj.2021.v17n5p1

Abstract

Objective: Italy and Germany are two large economies of the European Union. However, they differ with regard to culture, business environment structure, as well as social and political concerns. This paper focuses on how Chinese takeovers are perceived by stakeholders as reflected in the national press in Italy and Germany, and compares stakeholders' perceptions in two major national news magazines. Method: Stakeholders' perceptions were retrieved by adopting a qualitative approach which unfolds in a detailed and specific procedure. The textual elements referring to perceptions were categorized on the basis of specific questions. To ensure objectivity, the authors carried out independent reading and rating and the assessment of positive, neutral, and negative perceptions. Results: The German government highlights the growing awareness of a one-sided technology drain, while the Italian tends to perceive China as a negative investor. German and Italian shareholders have positive perceptions due to economic benefits. However, employees seem to have no voice. Conclusions: Factors related to national culture and business environments may be due to the fact that employees have no voice in the national press articles. Contributions: This study contributes to interpreting the phenomenon host 
country stakeholders, especially employees, who are under-represented.

Keywords: Acquisitions/Takeovers, China, Europe, Germany, Italy, Press, Host Country Stakeholders, Comparative Studies of Countries

\section{Introduction}

Since early 1990s, when Chinese firms began to invest in foreign assets, an increasing number of scholarly and practitioner-oriented articles were published. These articles shed light on the fact that Chinese firms acquired equity from companies all over the world, especially in developed economies and in a wide range of sectors such as heavy industry, logistics and transportation, telecommunication, and environmental industries (Mathews, 2006; Buckley et al., 2007; Klossek et al., 2012; Ludovico, 2013; ParejaAlcaraz, 2017).

Europe has become a key destination for Chinese investments. In 2016, Chinese firms invested $35 \mathrm{bn} €$ in the European Union, which is a $77 \%$ increase from the previous year (Rhodium group, 2017). According to MERICS (2017), over the last sixteen years, the majority of Chinese FDI into Western Europe went to UK (23,6 bn€), Germany (18,8 bn€), and Italy (12,8 bn€). Hence, notable and increasing attention is paid to European countries as target destinations ${ }^{1}$ in search for markets, innovation, and brands (Rhodium group, 2016).

The fact that companies from the PRC, currently pursuing and implementing selective industrial policies to become technology leader in the future (Wübbeke et al., 2016), have acquired German technology firms that possess critical assets has led to growing concern among lobbyists, politicians, and the public. This has further triggered off debates on Chinese acquisitions. In Italy, the threat of Chinese firms acquiring unique brands and craftsmanship talents, combined with the possibility of eventually closing down local plants and transferring production to China, has spurred heated debates as well (Ricciardi, 2016). Therefore, Germany and Italy provide good examples of policy and public opinion debates on Chinese acquisitions to be further investigated.

In line with the current trend of booming Chinese investments, this paper accordingly focuses on Italy and Germany as key target destinations of Chinese acquisitions. Leveraging on the similarities and differences between the two countries in terms of national culture, quality of institutions, and the features/dynamics of business system, the authors of this paper investigate the perceptions of different stakeholders in Germany and Italy on Chinese takeovers as reflected in the press.

\footnotetext{
${ }^{1}$ With outflows worth $\$ 128$ billion, China remains the third largest investing country
} worldwide, after the United States of America and Japan (UNCTAD, 2016). 
Extensive literature investigates stakeholders in the context of Chinese crossborder acquisitions in Europe (e.g., Meunier et al., 2014), while focusing more on the shareholders of the acquiring company rather than those of the acquired firms (Du \& Boateng 2015; Tao et al., 2017). The objective of this paper is to fill this void by analyzing perceptions of the acquired companies' stakeholders in the context of Chinese acquisitions in Italy and Germany. In addition to the shareholders, the authors analyze two other categories, namely employees/unions and government.

Specific attention is devoted to employees based on the following perspectives: firm - its competitiveness in terms of local know-how, high tech - in the case of Germany, and high quality handicrafts skills - in the case of Italy which lies in their hands and minds. Having their voice represented in the national press is fundamental since they constitute the key asset within the local territory of the host country as well (Burgoon \& Raess, 2014). Accordingly, this paper focuses on answering the following questions:

1. How are Chinese takeovers perceived by stakeholders in the host country? Is each category represented in the press? Are negative, neutral or positive perceptions represented in the economic reasoning of the respective host country?

2. Are there relevant national differences between Italy and Germany, and are they caused by cultural, economic, institutional or other reasons?

To achieve their objective, the authors rely on the analysis of similarities and differences related to national culture (Trompenaars, 1993; Hofstede, 2001) and business systems (Whitley, 2001). More specifically, they refer to these frameworks since it is possible to retrieve the most salient characteristics of the examined host countries and also highlight their similarities and differences, which might affect the magazines' focus and stakeholders' perceptions. According to Whitley (2010), a business environment is described as a series of practices and values which characterize the relations within a firm and between the firm and its external environment. These relations strongly affect a firm's actions and development. It also involves the firm's stakeholders as economic actors, whose perceptions constitute the main focus of this study. In other words, the business environment can be described as the "social, cultural, economic, political, and legal arena in which business activity takes place" (Quintanilla, 2000, p.6). Elements such as cultural traits and background shape a particular national business environment and may affect or mirror its stakeholders' perceptions. This study contributes to fill the void by investigating how the perceptions of host country stakeholders are represented in the press. According to the authors, "Perception" is the process of interpreting a situation in order to 
produce a meaningful experience based on prior experiences (Pickens, 2005). Furthermore, this study highlights the importance of employees and their voice for the success of the M\&A as reflected in the public opinion. This, however, seems to be under-represented with regard to the examined countries in the current literature.

\section{Germany and Italy as Target Countries of Chinese Takeovers}

Extensive research has recently covered Chinese acquisitions in Europe with a particular focus on Germany (Klossek et al., 2012; Ramasamy et al., 2012; Hanemann \& Huotari, 2016; Liedtke, 2017; Vaccarini et al., 2017) and Italy (Bellabona \& Spigarelli, 2010; Pareja-Alcaraz, 2017).

Until 2000, Chinese investors' were attracted by advanced manufacturing capabilities, technical know-how, and reputed brands, especially automotive and industrial equipment. More recently, IT, finance, and business services have drawn increasing interest (Henemann \& Huotari, 2016). Important reasons for Chinese investors are the acquisition of technology and the seal of quality Made in Germany. In 2014, Germany was the third largest recipient of Chinese investment in Europe, after Luxembourg and United Kingdom. According to the Chinese Ministry of Commerce, Chinese investments in Germany in 2016 increased by 200\% compared with the previous year (Bertelsmann Stiftung, 2016). In the case of Italy, luxury Made in Italy brands related knowledge, specific competencies, and strategic logistic locations to penetrate European markets have so far attracted Chinese investors' interest (Spigarelli, 2009).

Two important pre-requisites for the study of perceptions in the international business setting - Chinese acquisitions in Italy and Germany are the national cultural background and the context, i.e., the features of the business system. Therefore, cultural dimension models can be very useful. According to the results of Hofstede (Franke et al., 1991; Hofstede, 2001) and Trompenaars (1993), these countries have very different cultural backgrounds and values that are reflected in different business behaviors and business approaches. Although Italy and Germany are both highly individualistic and male chauvinist societies, they still differ in the degree of such dimensions ${ }^{2}$. These cultural aspects have huge consequences for the organizational culture, management style, and perceptions of economic actors (Spigarelli et al., 2009).

While focusing on the concept of comparative business systems, Whitley's framework is useful to contextualize Italy and Germany (Whitley, 2010). Consequently, the key differences in systems of economic organization and control can be identified in terms of specific features of the institutional

2Italy: [online; October 2017], available from: https://geert-hofstede.com/italy.html, Germany: [online; October 2017], available from: https://geert-hofstede.com/germany.html. 
environment (Whitley, 1999). Different types of business environments emerge on the basis of the institutional arrangements controlling access to capital and skills; the forms of coordination and control of economic activities, which lead to different strategic priorities; and forms of owner control, authority sharing, and collective competencies.

Leveraging from a cultural and business framework of analysis, the authors depict some key similarities and differences between Italy and Germany, which may affect the perceptions of host country stakeholders. Next to France and the UK, both countries are among the biggest manufacturing countries in Europe and the most important economies of Western Europe (Sviluppo Economico, 2017). "Industry is a significant driver of the German and Italian economies, which is usually considered as the EU's most "industrial" countries. More so, both economies feature the highest per capita values of industrial production in the world". Both countries also have "high levels of worldwide manufacturing exports" (Arrighetti et al., 2012, p. 5).

After a period of investment in Southern Europe, Germany, as one of the "Big Three" European economies along with France and the UK, was targeted by Chinese investors in 2016. Nevertheless, Southern European countries, such as Italy, have been experiencing steady interest by Chinese (Hanemann \& Huotari, 2017). Italy and Germany have had their small and medium enterprises (SMEs) ${ }^{3}$ targeted by Chinese firms since these offer consumer markets, safe havens, and advanced manufacturing assets (i.e., Germany) as well as handicraft and brands (i.e., Italy) (Hanemann \& Huotari, 2016). Thus, both countries present similar institutional settings. Germany SMEs account for about $99.7 \%$ of all kind of companies, while Italy accounts for about $99.8 \%$ (Abel-Koch et al., 2015). However, these very similar figures hide relevant differences at the micro firm level in terms of weight of value added which is generated by very small firms and the average number of employee per firm (Arrighetti et al., 2012).

The majority of firms within the two business systems are small and medium, but the composition is highly different. This is seen with Italy mostly based on micro firms, which is typically nested within industrial district networks. More than $95 \%$ of firms have less than 9 employees. This means that microbusinesses generate more that $43 \%$ of value added and absorb around $59 \%$ of employees. Germany relies more on medium firms (which produce $37.2 \%$ of added value) and small firms (which occupy $37.17 \%$ of active population) (Table 1 ).

${ }^{3}$ SMEs are "defined as micro, small, and medium-sized enterprises with less than 250 employees" (Abel-Koch et al., 2015, p.38). 
Table 1. SMEs in Italy and Germany

\begin{tabular}{|r|c|c|c|c|c|c|}
\hline & \multicolumn{3}{|c|}{ Germany } & \multicolumn{3}{c|}{ Italy } \\
\hline No. of Firms (\% of total ent.) & Micro & Small & Medium & Micro & Small & Medium \\
\hline 2010 & 82.59 & 14.84 & 2.57 & 94.68 & 4.81 & 0.51 \\
\hline 2016 & 82.56 & 14.92 & 2.52 & 95.22 & 4.29 & 0.49 \\
\hline No. of employees (\% of total ent.) & Micro & Small & Medium & Micro & Small & Medium \\
\hline 2010 & 30.44 & 36.93 & 32.63 & 58.14 & 26.6 & 15.26 \\
\hline 2016 & 30.07 & 37.17 & 32.76 & 58.77 & 25.4 & 15.83 \\
\hline Value added (\% of total ent.) & Micro & Small & Medium & Micro & Small & Medium \\
\hline 2010 & 27.75 & 34.3 & 37.94 & 43.95 & 31.46 & 24.59 \\
\hline 2016 & 28.9 & 33.9 & 37.2 & 43.53 & 31.24 & 25.23 \\
\hline
\end{tabular}

(Source: http://ec.europa.eu/growth/smes/ ${ }^{4}$ ).

Italy delivers most of the added value by leveraging on micro firms. Also, the relatively small size of the companies is particularly appealing to Chinese investors (Moscarini \& Postel-Vinay, 2012).

The differences between Italy and Germany can be summarized as follows: "the traits of the German and Italian economies differ significantly and [in our opinion], the biggest differences are structural, mostly related to the size of the firms, the quality and supply of human capital produced by the educational system, the export policy, and the government research policies implemented and their practical relation to the economic interests of the relative country" (Arrighetti et al., 2012, p. $8)$.

From a cultural perspective, the division between Germany and Italy epitomizes specific differences in communicative contexts such as the expression of feelings or the willingness to talk about certain topics. In this case, it can be seen how stakeholders relate with the press through the expressions of perceptions. Cultural dimensions such as collectivism/individualism or high/low-context may apply in this case (Trompenaars, 1993; Hofmann, 1999; Hofstede, 2001). This may provide a better understanding of the phenomenon of stakeholders' perceptions whether the authors' categories of stakeholders express their perceptions and the information or perceptions they are keen on disclosing. Low/high-context is

\footnotetext{
${ }^{4}$ Entrepreneurship and Small and medium-sized enterprises (SMEs), [online; October 2017], available from: http://ec.europa.eu/growth/smes/.

${ }^{5}$ In particular, with respect to Italy, firms are typically run by families and located in industrial districts spread all over the country (Aureli et al., 2010; Mucelli et al., 2015). For example, Marche, Tuscany, and Veneto lead the shoe manufacturing sector in terms of density of companies $(69.6 \%)$ and employees $(66.5 \%)$. Although industrial districts can be found even in the South area, the majority of them are located in Northern and Central Italy (Mucelli et al., 2015).
} 
related to the communication processes in collectivistic and individualistic cultures (Hofmann, 1999).

The authors of this paper refer to low/high-context communication in the flow of information exchange. Therefore, "context has to do with how much you have to know before you can communicate effectively" (Hofmann, 1999, p.4). Collectivist cultures emphasize the group level and refer to those societies which are strongly integrated within cohesive groups. Individualism is more focused at the level of the individual and the ties among group members are loose. China can be defined as a high-context and collectivist culture and in the case of business issues, pieces of information are disclosed to every in-group member so that everyone belonging to that group can be constantly updated. This is likely to affect the communication dynamics in the host country. In low-context and individualistic cultures, such as Germany, pieces of information are not constantly exchanged. Moreover, only the most necessary issues related to business are disclosed. In contrast, Italy is similar to China for some traits and similar to Germany for some others. It is more high-context oriented than Germany since business is usually done with people, with whom individuals are familiar (e.g., similarity to China). However, the degree of interdependence among group members is loose (e.g., similarity to Germany) (Hofstede, 2017).

\section{Methodology}

In order to retrieve stakeholders' perceptions as expressed in the German and Italian national press, the authors initially thought to search for specific keywords in articles in leading German and Italian business-oriented newspapers, i.e., Wirtschaftswoche and Handelsblatt for Germany; Il Sole 24 Ore and Borsa e Finanza for Italy. The authors' intention was to look for negative and positive words reflecting perceptions such as 'fear' (Italian: paura; German: Angst) or 'hope' (speranza; Hoffnung). They lacked electronic access to major newspapers and business-oriented magazines and were keen on avoiding the random sampling of articles. Thus, they decided to use a different approach, which is illustrated in the next paragraph. However, through this new approach, the authors could not retrieve such explicit in-text textual elements. Therefore, to pursue their objective and look for textual elements reflecting positive, negative and neutral perceptions, they opted for two alternative qualitative methods. The authors relied on members of their Italian team, who carried out the independent reading and rating of the textual elements of the Italian articles, which are illustrated in the next section.

In order to capture the salient perceptions of public opinions, authors firstly screened the popular weekly magazines Der Spiegel and L'Espresso, which are meant to be equivalent in terms of readership in both countries. They 
looked for articles in German and Italian ${ }^{6}$ language containing the word "China" (German) and "Cina" (Italian) in the full text and within the latest 12 months (February 2016-2017). The articles in these periodicals of national resonance report facts, figures, and news in a combination of objective and subjective style. Hence, they served the purpose of retrieving the perceptions of public opinions on Chinese acquisitions. The Italian L'Espresso accounts for 1.5 million readers per issue, while the German Der Spiegel accounts for 6.79 million readers per issue ${ }^{7}$.

This searching procedure for articles was followed by the analysis of the content aimed at finding the most recurrent textual elements reflecting positive, neutral, and negative perceptions (e.g., general sentiment, approval, disapproval). For the purpose of this study, the textual elements referring to perceptions were categorized on the basis of several questions: 1) Was the article's primary focus on Chinese acquisitions? 2) Which of the three stakeholders' perceptions was reported? 3) Did the positive, neutral or negative perceptions prevail by a certain category?

Negative perceptions have been related to words such as fear, threat, trouble, anxiety, evasion, sellout of national interests, job loss, and enemy. On the other hand, positive perceptions have been related to words such as hope, chance, opportunity, 'white knight', strategic partner, and win-win. Neutral perceptions were the outcome of a balanced evaluation between pros and cons or the result of objective reporting.

The above illustrated qualitative approach is derived from the critical discourse analysis - $\mathrm{CDA}^{8}$, which is used to capture the nuances of meaning of the textual parts. Its origin can be found in Michel Foucault's studies on power and discourse (Sinclair \& Coulthard, 1975; Fairclough, 1993). It was developed in response to the need for connecting the micro-linguistic aspects of the discourse (spoken and written textual elements) and its more macrosocial aspects (values and ideologies_- perceptions). The authors of this paper applied this method to written texts only, with the aim to relate positive/neutral/negative textual elements (words, expressions and concepts) with positive/neutral/negative subjective perceptions by stakeholders on Chinese acquisitions. They screened the textual parts, arranged the relevant

${ }^{6}$ The authors decided for the German and Italian language and excluded the English since they wanted to retrieve perceptions from the national readers of the respective countries.

${ }^{7}$ Der Spiegel (2017). http://www.spiegel-qc.de/medien/print/der-spiegel/eng, L'Espresso (2017) http://www.gruppoespresso.it/uploads/tx_cir/Company_presentation_1H_2016.pdf, (both accessed February 2017).

${ }^{8} \mathrm{CDA}$ is based on the analysis of the textual parts, the language, the most recurring words, expressions, and topics. The aim of this paper was to identify stakeholders' implicit perceptions, values, and meanings emerging from the articles related to both Italian and German contexts. The analysis is based on Van Dijk's approach (2000), whose purpose is to comprehend the relationship between values and texts and discourses as well as to comprehend how they help to reproduce these values in society. 
ones in a working sheet, and associated them with the respective stakeholder's category and perceptions. The independent reading and rating and the assessment of positive, neutral, and negative perceptions was carried out to ensure objectivity.

\section{Results}

The content analysis shows the combination of the objective and subjective parts of the text. The subjective part of the articles include information such as opinions, perceptions and emotions, while the objective part reports facts, figures, and details about the Chinese acquisition. Differences between the two national periodicals emerge in the degree of details used to report the news, especially in terms of objectivity. The content of the articles in the German Der Spiegel are more detailed in reporting facts regarding Chinese acquisitions than the Italian articles in L'Espresso. The authors further distinguish between quantity and quality of the news.

In terms of quantity, "Spiegel Online" (SO) reports a much higher number of results by using the term "China" as a keyword in the search engine of the periodical's website rather than their Italian counterparts. Out of $1590 \mathrm{SO}$ articles related to China, 64 report perceptions of stakeholders in general (e.g., Chinese exports and imports, China's entry in the WTO and the current US President's opinion of China). 39 SO articles specifically report stakeholders' perceptions on Chinese acquisitions in Germany. The Italian results regarding "Cina" account for 162 articles in "L'Espresso", 39 of which report perceptions on Chinese acquisitions by the three categories of stakeholders. 9 out of these 162 are specifically about stakeholders' perceptions ${ }^{9}$.

In terms of quality, i.e., how much in depth the news are reported, German articles seem to provide a more comprehensive description of the facts than Italian articles. Overall, German readers find more objective pieces of information in SO articles (reporting facts and figures) along with the subjective ones (i.e., perceptions) than the Italian.

\subsection{Germany}

The 64 articles that were identified and selected as possibly relevant for the objective of this paper were further screened and categorized based on the following questions below:

- Is the article primarily focused on the issue of Chinese expansion or takeovers in Germany?

- Which of the three stakeholder groups is mentioned, and what is their perception of the Chinese takeover/expansion?

${ }^{9}$ One article may contain perceptions regarding more than one stakeholder category. 
- What is the dominant perception regarding the consequences of the Chinese takeover?

40 articles published in SO explicitly addressed certain takeover processes that occurred in 2016. The other articles focused on more general issues regarding Chinese FDI or the impact of a possible U.S. - Chinese trade war in the aftermath of the Trump election.

The highest represented category in the German articles is the government category. Furthermore, only one article mentioned positive effects for the German economy as a result of increasing Chinese FDI. The authors, however, reported negative perceptions in 14 articles. Nonetheless, the majority of the articles (15) mentioned neutral reactions with regard to Chinese acquisitions in Germany. The neutral category had to be assigned to many articles because the journalists mainly reported on different objective aspects of the proposed deals or offers by Chinese companies (e.g., subsidiaries by the government, costs of the deal, share of equity to be acquired, voice).

Additionally, authors considered the fact that the 40 SO articles only covered a total of 10 deals (many of which remain unfinished to this day). Hence, cases are covered more than one time and some developments have been reported such as problems with the selling of the Airport Hahn (SO: 5.6.2016; 6.6.2016; 29.6.2016; 30.6.2016; 19.7.2016; 28.7.2016; 30.8.2016; 23.1.2017). Frequently, the titles of the articles showed the German Angst (fear): "Takeovers in Germany: Fear of China/Übernahmen in Deutschland: Angst vor China" (SO: 29.10.2016), "Manufacturer of Robots: Politics fear Selling Kuka to China/Roboterproduzent: Politik fürchtet Kuka-Verkauf nach China" (SO: 30.05.2016), or "Takeover of German Firms: "China exploits European Liberalism one sided", "Übernahmen deutscher Unternehmen: "China nutzt die Offenheit in Europa einseitig aus" (SO: 16.11.2016).

However, some lobbyists and politicians seem to be less concerned: "Takeovers: DIHK-President warns of investment barriers against China/Übernahmen: DIHK-Präsident warnt vor Investitionsschranken gegen China" (SO: 24.10.2016).

Shareholders follow the previous category in terms of number of perceptions reported (16 times), and the majority is positive (7). More so, the takeover target firms have been in trouble. Therefore, a takeover offer from China increased the share price and consequently the investment of the investors. Furthermore, Grammer AG, an investment by Jifeng - a Chinese SME - is seen as a "white knight", given that the company has to fight against another investor from Bosnia: "Fight against Investor: Automotive supplier Grammer gets help from China/Kampf gegen investor: Autozulieferer 
Grammer bekommt Hilfe aus China" (SO: 14.2.2016). Six (6) articles reported that the takeover is principally advantageous, but the future holds the answers as to whether there are negative results such as a drain of knowledge. Only a few articles express negative perceptions that are mainly due to the long-term prospects of the acquired firm.

With rare exceptions, there is no report about the perceptions and feelings of employees and/or reactions by their representatives, i.e., unions (6 articles). The article titled "Chinese Investor: Osram's workforce fights against takeover/Chinesischer Investor: Osram-Belegschaft stemmt sich gegen Übernahme" (SO: 23.11.2016) is the only article that reports skepticism. It is mentioned, among others, that employees are afraid of losing patents and subsequently jobs. However, as mentioned above, the acquired firms are frequently in some kind of business crisis. Therefore, it is not surprising that Chinese investors are perceived as job-savers. This is exemplified by the case of Kuka: "Midea guarantees for the next seven and a half years 12,300 Kuka jobs and the maintaining of the HQs in Augsburg, where 3,500 people work. IG Metall [Note: major German industrial union] has also expressed its consent/Midea garantiert demnach für die nächsten siebeneinhalb Jahre den 12.300 Kuka-Beschäftigten ihre Jobs und den Erhalt der Unternehmenszentrale in Augsburg, in der allein 3500 Menschen arbeiten. Auch die IG Metall hatte sich daher zustimmend zu der Vereinbarung geäußert.” (SO: 29.6.2016). Amongst the six articles that mentioned employee or union reactions, three were positive, two were neutral, and one (mentioned above) was negative.

The following table (Table 2) illustrates some of the major acquisitions of German firms by Chinese companies as reported in $\mathrm{SO}$ within the time period of February 2016-2017.

Table 2. Examples of recent acquisitions in Germany mentioned by the examined articles

\begin{tabular}{|c|c|c|c|c|c|}
\hline \multirow{2}{*}{$\begin{array}{l}\text { German } \\
\text { acquired } \\
\text { company }\end{array}$} & \multirow{2}{*}{$\begin{array}{c}\text { German Land } \\
\text { - Federal State }\end{array}$} & \multicolumn{2}{|c|}{ Chinese investors } & \multirow[t]{2}{*}{ Industry/products } & \multirow{2}{*}{$\begin{array}{c}\text { Year of } \\
\text { acquisition }\end{array}$} \\
\hline & & Private & State-owned & & \\
\hline $\begin{array}{l}\text { Airport } \\
\text { Hahn }\end{array}$ & $\begin{array}{c}\text { Hesse \& } \\
\text { Rhineland- } \\
\text { Palatinate }\end{array}$ & $\begin{array}{c}\text { HNA } \\
\begin{array}{c}\text { Not decided } \\
\text { yet }\end{array} \\
\end{array}$ & - & Airport & 2016 \\
\hline $\begin{array}{c}\text { Aixtron } \\
\text { AG }\end{array}$ & Lower Saxony & $\begin{array}{l}\text { Fujian Grand } \\
\text { Chip (FGC) } \\
\text { Investment }\end{array}$ & Sino IC & $\begin{array}{l}\text { Chip equipment } \\
\text { manufacturer }\end{array}$ & 2016 \\
\hline $\begin{array}{c}\text { Broetje- } \\
\text { Automatio } \\
\text { n GmbH }\end{array}$ & Lower Saxony & $\begin{array}{c}\text { Shanghai } \\
\text { Electric Group }\end{array}$ & - & $\begin{array}{l}\text { Machinery and } \\
\text { equipment } \\
\text { manufacturer }\end{array}$ & 2016 \\
\hline $\begin{array}{c}\text { Carcoustic } \\
\mathrm{s}\end{array}$ & $\begin{array}{l}\text { North Rhine- } \\
\text { Westphalia }\end{array}$ & $\begin{array}{l}\text { Liaoning Dare } \\
\text { Industrial } \\
\text { Company }\end{array}$ & - & $\begin{array}{l}\text { Supplier to the } \\
\text { automotive } \\
\text { industry }\end{array}$ & 2016 \\
\hline
\end{tabular}




\begin{tabular}{|c|c|c|c|c|c|}
\hline $\begin{array}{l}\text { EEW } \\
\text { GmbH }\end{array}$ & Lower Saxony & - & $\begin{array}{c}\text { Beijing } \\
\text { Enterprises } \\
\text { Holdings Ltd. }\end{array}$ & $\begin{array}{l}\text { Waste management } \\
\text { company }\end{array}$ & 2016 \\
\hline $\begin{array}{l}\text { Grammer } \\
\text { AG }\end{array}$ & Bavaria & Jifeng & - & $\begin{array}{l}\text { Supplier to the } \\
\text { automotive } \\
\text { industry }\end{array}$ & 2016 \\
\hline $\begin{array}{l}\text { Hauck \& } \\
\text { Aufhäuser }\end{array}$ & Hesse & $\begin{array}{l}\text { Investment } \\
\text { Fond Fosun }\end{array}$ & - & Private Bank & 2016 \\
\hline Manz AG & $\begin{array}{c}\text { Baden- } \\
\text { Württemberg }\end{array}$ & & $\begin{array}{c}\text { Shanghai } \\
\text { Electric } \\
\text { Group Co., } \\
\text { Ltd. }\end{array}$ & $\begin{array}{c}\text { Electronic } \\
\text { components and } \\
\text { devices }\end{array}$ & 2016 \\
\hline $\begin{array}{c}\text { KraussMaf } \\
\text { fei } \\
\text { Technolog } \\
\text { ies GmbH }\end{array}$ & Bavaria & - & $\begin{array}{c}\text { ChemChina } \\
\text { (China } \\
\text { National } \\
\text { Chemical } \\
\text { Corporation) }\end{array}$ & $\begin{array}{c}\text { Industrial } \\
\text { machinery maker }\end{array}$ & 2016 \\
\hline KUKA AG & Bavaria & - & Midea Group & $\begin{array}{l}\text { Roboter and } \\
\text { equipment } \\
\text { manufacturer }\end{array}$ & 2016 \\
\hline $\begin{array}{l}\text { Osram - } \\
\text { Ledvance }\end{array}$ & Bavaria & - & $\begin{array}{c}\text { Consortium } \\
\text { MLS \& } \\
\text { San'an } \\
\text { Optoelectroni } \\
\text { cs }\end{array}$ & Lighting & 2016 \\
\hline $\begin{array}{c}\text { KION } \\
\text { GROUP } \\
\text { AG }\end{array}$ & Hesse & - & $\begin{array}{c}\text { Weichai } \\
\text { Power (part } \\
\text { of Shandong } \\
\text { Heavy } \\
\text { Industry } \\
\text { Group Co., } \\
\text { Ltd.) }\end{array}$ & $\begin{array}{l}\text { World's leading } \\
\text { manufacturer of } \\
\text { industrial trucks }\end{array}$ & 2012 \\
\hline $\begin{array}{l}\text { Putzmeiste } \\
\text { r Holding } \\
\text { GmbH }\end{array}$ & $\begin{array}{c}\text { Baden- } \\
\text { Württemberg }\end{array}$ & $\begin{array}{c}\text { Sany Heavy } \\
\text { Industry Co., } \\
\text { Ltd. } \\
\text { (Changsha) }\end{array}$ & - & $\begin{array}{l}\text { Manufacturer of } \\
\text { concrete pumps }\end{array}$ & 2012 \\
\hline $\begin{array}{l}\text { Kiekert } \\
\text { AG }\end{array}$ & $\begin{array}{l}\text { North Rhine- } \\
\text { Westphalia }\end{array}$ & $\begin{array}{c}\text { Hebei } \\
\text { LingYun } \\
\text { Industrial } \\
\text { Group Co., } \\
\text { Ltd. (Zhuozho } \\
\text { u) }\end{array}$ & - & $\begin{array}{l}\text { Global supplier of } \\
\text { automotive locks }\end{array}$ & 2012 \\
\hline $\begin{array}{l}\text { Tailored } \\
\text { Banks }\end{array}$ & $\begin{array}{l}\text { North Rhine- } \\
\text { Westphalia }\end{array}$ & - & $\begin{array}{l}\text { Wuhan Iron } \\
\text { and Steel } \\
\text { Corporation }\end{array}$ & $\begin{array}{l}\text { World's largest } \\
\text { Steel producer }\end{array}$ & 2012 \\
\hline
\end{tabular}

(Source: SO, February 2016-2017). 


\subsection{Italy}

The Italian results regarding "Cina" count 162 articles, 39 of the articles report perceptions on Chinese acquisitions. 9 out of these 162 articles are specifically about perceptions of the three categories of stakeholders. In the case of Germany, they were considered as potentially interesting for the authors' analysis and were categorized based on the questions reported in the previous section. The articles explicitly addressed specific takeovers which occurred between 2012 and 2016 (Table 3).

The highest represented category in the Italian articles (6) from L'Espresso (E) is the government category. According to the main findings, representatives from this category mostly show negative perceptions toward Chinese acquisitions in Italy. Some significant sentences appear in the titles: "with China, Italy plays counterattack/con la Cina l'Italia gioca in contropiede" or in the text of the news such as: "Chinese colossus/colosso cinese" (E: 5.12.2016). In 4 out of 7 articles, the overall feeling is negative as the above mentioned textual elements confirm. However, a neutral and a positive quotation can also be found: "Beijing is, overall, a determinant partner but cumbersome at the same time/Pechino, insomma, è un partner determinante ma, allo stesso tempo, ingombrante" (E: 5.12.2016). Along with the Italian government, other negative perceptions at European level are reported in the articles and, in a parallel way to the German ones, they refer to the post-Trump election period.

Articles regarding shareholders' perceptions (4) show positive textual elements, reflecting no fear of China. This is confirmed by expressions such as: "There is no reason to be Sino-phobic/Non esiste ragione di essere sinofobi" (E: 26.7.2016 - Turano, 2016), and: "this is a detail which does not undermine optimism/questo è un particolare che non scalfisce l'ottimismo" (E: 26.10.2016). Italian shareholders, especially the ones of the acquired company headquartered in Milan, Lombardy (Table 3), represent one of the national most successful football clubs. AC Milan reports a positive perception about the Chinese acquisition: "the new owners have no shortage of money/non che manchino i soldi ai nuovi proprietari" (E: 26.7.2016 Turano, 2016). Along with fashion, Italian soccer clubs are increasingly targeted by Chinese investors. In general, the entertainment industry is gaining more and more attention by Chinese acquirers. This is as a result of the "the new normal" way of living of Chinese people (Ricciardi, 2016). AC Milan's acquisition provides evidence of the shifted and growing interest by Chinese investors in the Western entertainment industry, which ranges from football to tourism ( $\mathrm{Li}$ et al., 2017). The same deal was not positively seen by government: "the Serie-A takeover [...] by the Popular Chinese Republic is not necessarily a positive element/il takeover della serie A da parte della Repubblica Popolare Cinese [...] non è necessariamente un elemento 
positivo" (E: 26.7.2016 - Turano, 2016). A different picture emerges with reference to the Pirelli deal. Here, a very positive perception was reported by referring to the "integration of Pirelli and ChemChina activities/integrazione delle attività di Pirelli e di quelle di ChemChina". Pirelli represented the largest deal in Europe in 2015 (7.1 billion euros) and the fifth largest ever for a Chinese group (Arosio \& Masoni, 2015).

In the case of Italy, no articles could be found concerning the perceptions of employees or the reactions by their representatives. The following table (Table 3) illustrates some of the major Chinese acquisitions in Italy appearing in the articles.

Table 3. Examples of recent acquisitions in Italy mentioned in the examined articles

\begin{tabular}{|c|c|c|c|c|c|}
\hline \multirow{2}{*}{$\begin{array}{c}\text { Italian } \\
\text { acquired } \\
\text { company }\end{array}$} & \multirow{2}{*}{$\begin{array}{l}\text { Italian } \\
\text { Region }\end{array}$} & \multicolumn{2}{|c|}{ Chinese investors } & \multirow[t]{2}{*}{ Industry/products } & \multirow{2}{*}{$\begin{array}{c}\text { Year of } \\
\text { acquisition }\end{array}$} \\
\hline & & Private & State-owned & & \\
\hline $\begin{array}{c}\text { Terra Moretti } \\
\text { Holding } \\
\text { (former } \\
\text { Gruppo } \\
\text { Campari) } \\
\end{array}$ & Lombardy & $\begin{array}{l}\text { Cheng } \\
\text { Pao } \\
\text { family } \\
\text { (Hong }_{\text {Kong) }}{ }^{10} \\
\end{array}$ & - & Premium wines & 2016 \\
\hline $\begin{array}{c}\text { AC Milan } \\
\text { (owned by } \\
\text { Fininvest spa) }\end{array}$ & Lombardy & - & $\begin{array}{c}\text { State Development } \\
\text { \& Investment } \\
\text { Corporation } \\
\text { (Beijing) }\end{array}$ & $\begin{array}{l}\text { Professional football } \\
\text { club }\end{array}$ & 2016 \\
\hline $\begin{array}{c}\text { Pirelli \& C. } \\
\text { spa }\end{array}$ & Lombardy & - & $\begin{array}{c}\text { ChemChina (China } \\
\text { National Chemical } \\
\text { Corporation) } \\
\text { (Beijing) }\end{array}$ & Tyre manufacturer & 2015 \\
\hline $\begin{array}{l}\text { Ansaldo } \\
\text { Energia }\end{array}$ & Liguria & - & $\begin{array}{l}\text { Shanghai Electric } \\
\text { Group Company } \\
\text { Limited (Shanghai) }\end{array}$ & $\begin{array}{l}\text { Power engineering } \\
\text { company }\end{array}$ & 2014 \\
\hline Ferretti Group & Marche & - & $\begin{array}{l}\text { Weichai Group } \\
\text { (part of Shandong } \\
\text { Heavy Industry } \\
\text { Group Co., Ltd. - } \\
\text { SHIG) (Jinan) }\end{array}$ & $\begin{array}{l}\text { Manufacturer of } \\
\text { luxury yachts }\end{array}$ & 2012 \\
\hline
\end{tabular}

(Source: L'Espresso, February 2016-2017).

\subsection{Comparative Analysis}

While the German government seems to remain quite neutral, the Italian perception of this category is more negatively oriented and skeptical. According to the text analysis, China is seen as a colossus or giant (E:

\footnotetext{
${ }^{10}$ The investor Cheng Pao family is from Hong Kong, not from mainland China. Sella and Mosca (Sardinia) and Teruzzi and Puthod (Tuscany) were sold from Gruppo Campari to Terra Moretti Distribuzione, which is controlled by Terra Moretti spa, Simest spa and participated by N.U.O. Capital. N.U.O. Capital is an investment company recently promoted by the Cheng Pao family.
} 
5.12.2016) which strongly influences today's interdependent world scenario. Its "colossal" influence could be both positive and negative and can affect not only business relationships, but also political partnerships.

Among the three categories of stakeholders, articles regarding perceptions of employees or unions are far lower. Employees seem to be highly disregarded at least in the two weekly news magazines that the authors selected. While in Germany, at least one of the articles reports their perceptions, but the Italian press seemed to give no voice to the employees. In Germany, the relevant article reports that Chinese acquisitions are perceived not only negatively by this group, but a sentiment of fear is made explicit by words such as "Alarm" (alarm) and "beführchten" (they are scared). In that article, the unionists representing German employees warn Chinese investors about the Osram lighting manufacturer bid, since they fear for the Bavarian company and its workers. More specifically, they indicate their backlash against Chinese involvement in the nation's high-tech sector, which may end up in Chinese hands. This in turn will provoke fear over the possibility of losing jobs and plant guarantees.

The Shareholders ' perceptions proved to be positive both in Germany and Italy, with only few articles reporting a neutral or negative sentiment. The takeovers are likely to be seen as advantageous due to pre-acquisition hidden motives such as the opportunity for the acquired companies to be "saved" by wealthy, private or state-owned Chinese investors (E: 26.7.2016 - Turano, 2016).

\section{Discussion}

Some commonalities and some differences can be highlighted as a result of the authors' analysis on stakeholders' perceptions. The screening process from $L$ 'Espresso magazine resulted in news and reports only on the most salient (financially the biggest) deals in Italy. This is confirmed by the Pirelli-ChemChina case. However, compared to Germany, whose business system also includes large and medium firms, Italy is particularly characterized by small and micro enterprises which are increasingly targeted by Chinese investors ${ }^{11}$. By having a look at Table 3, the Chinese acquisitions

\footnotetext{
${ }^{11}$ Analytic data for Italy show that acquisitions take place not only in the big industrial cities of the north, such as Milan and Turin, but also in minor areas of the country, as well as in industrial districts in the Central and South Italy. The acquired companies operated in the following industries: logistics, transportation, manufacturing, wholesale, telecommunications and they are likely to be "anonymous" SMEs to the national or international public (Ludovico, 2012, p.23) . These facts confirm how Chinese "anonymous" investors commit their equity in the Italian system. The growth-generating potential of SMEs has been the subject of many scholarly studies. Although there is no consensus in the literature on whether SMEs enterprises generate more growth than large enterprises, the size of these companies is particularly appealing to Chinese investors. This, in comparison to larger firms in Germany (Moscarini \& Postel-Vinay, 2012), is pushed by the popularity of the Made in Italy.
} 
between 2012 and 2016 reported in the Italian press are located in the Northern and Central part of the country, where the major industrial districts are located (Mucelli et al., 2015). This presence combined with micro and larger firms probably draws the attention of foreign investors due to the development of networks within the districts. This enhances the balance between cooperation and competition, not only at a national level but also at an international level (Aureli et al., 2010). The attention devoted by the press to big deals might explain the fact that the perceptions of employees and unions are underrepresented. The authors of this paper will motivate this at the end of the section.

Recent studies seem to confirm that large enterprises are affected more by international business cycles and interdependence among countries than SMEs (Moscarini \& Postel-Vinay, 2012). This might confirm the Italian national economy's (government) perceptions of fear. Thus, in the case of a decreasing Chinese economic trend, the Italian system would also be affected. This may have implications for how national economies behave during economic depression phases in terms of different business sectors.

- The positive perceptions of shareholders in both German and Italian articles seem to ignore cultural elements. In this regard, a recent research analyzing a sample of 367 cross-border acquisitions by Chinese listed companies between 2000 and 2011 is worth mentioning, despite the fact that it adopts the perspective of the acquirers' shareholders (Li et al., 2016). This study focuses on relating the value creation for the Chinese investor and the cultural distance. According to the main results, the examined transactions created value for the Chinese investors despite cultural distance issues. Conversely, textual elements of the analyzed articles referring to cultural distance seem not to be available. Nevertheless, the Pirelli shareholders' statement about the integration of Pirelli and ChemChina activities may lead to the conclusion that the Chinese acquisition successfully overcame cultural barriers. Cultural aspects are known to be crucial issues in the international business literature (Shenkar, 2012; Vaara, Sarala, Stahl \& Bjorkman, 2012). Cultural distance is often cited as an obstacle to integrating acquisitions (Morosini, Shane \& Singh, 1998). However, the examined articles in this paper which is addressed to the common readership do not face this crucial aspect but remains latent. This may be the reason why the scientific community readership has been deeply committed in covering cultural issues not only from an international business perspective but also from other research areas (Mueller et al., 2012). Emerging market multinationals may be affected by cultural distance since they typically lack international experiences and tend to 
learn once the internationalization process has started, rather than implementing their existing knowledge (Li et al., 2016).

- The lack of a voice for employee unions in the examined article may hide underlying cultural reasons. The disclosure of employee perceptions toward Chinese takeovers may be linked to the cultural dimension low-/high-context. While the Chinese (high-context), who are the acquirers, commonly announce their final decision after agreement, the German (low-context) decision making process usually takes place during the agreement. The Chinese's attitude is deeply rooted in the perceived importance of "keeping their face". This cultural trait seems to have gained ground in the case of Italy, where the acquired stakeholders mirror the acquirers' attitude. From the perspective of the low/high-context dimension, Italy is closer to China than Germany is. By applying this phenomenon to the case, this cultural trait may explain the tendency to disclose information regarding overseas acquisitions very carefully or in the late stages of the deal, as many articles in the national press confirm. This is particularly true for the Italian takeovers, which are usually disclosed after the negotiation.

- Considering Whitley's (2010) business environment as the social, cultural, economic, political, and legal arenas in which business activities take place, the relationships between stakeholders are taken into account. These relations, which exist within and between firms, strongly affect the perceptions of economic actors involved in the examined overseas takeovers. Whitley $(2010$, p.17) argues that "states differ in their toleration of, and support for, intermediary groups and associations between individuals, firms, and the state that play a significant role in coordinating economic developments. These groupings include trade associations, employers' groups, and labor unions. This feature can be summarized as the degree of state support for intermediary organisations. While some European countries seem to be more tolerant, other countries such as Germany appear to positively support the presence of these groupings, which are basically organizations created within and between sectors. With regard to Italy, there is no example provided by this framework. Furthermore, this study aims to formulate a deeper investigation on the extent to which the state is keen on tolerating or encouraging the formation of such organizations. Despite one result, this may be the reason why the German national press shows, at least, a minimum consideration of the voice of the employees compared to the Italian press, whose articles do not take into account the perceptions of employees. 


\section{Conclusion}

Consequently, some limitations of the paper need to be addressed. The authors used two sources to collect data, the Italian L'Espresso and the German equivalent Spiegel Online. The search engine on the periodicals' websites allowed the authors to look for articles within a time frame of 12 months.

The content analysis showed the combination of the objective and subjective parts of the text. The subjective part of the articles includes information such as opinions, perceptions, and emotions. On the other hand, the objective part reports facts, figures, and details about the Chinese acquisition. Differences between the two national periodicals emerge in the degree of details used to report the news, especially in terms of objectivity. The content of the articles in the German Der Spiegel are more detailed in reporting facts regarding Chinese acquisitions than the Italian articles in L'Espresso. Thus, the authors distinguished between quantity and quality of the news in reporting their results.

- This paper focused on investigating how Chinese takeovers in Europe are perceived by stakeholders as reflected in the national press. Italy and Germany were chosen as the countries of investigation because they constitute two large economies of the European Union. However, they differ with regard to culture, business environment structure, and social and political concerns.

- Results indicate that the German public, especially the government, reacts with growing awareness of a one-sided technology drain. Also, while shareholders expect economic benefits, information regarding employee perceptions is rare. With regard to the Italian public, employee perceptions are not reported in the press. Factors related to national culture and business environments may lie behind the lack of employee voice in the national press articles.

- This paper makes several contributions to the growing literature on the Chinese "Go global" policy. The authors add an important aspect that has been widely neglected so far, i.e., the perceptions of stakeholders of foreign companies that are targeted by Chinese FDI and, in particular, the employees' voice in a wider socio-cultural and socioinstitutional context of the host country.

- As for policy implications, the growing awareness in Germany may lead to an increasingly negative attitude concerning future takeover attempts. Politicians need to develop adequate measures to cope with it. Conversely, Italy's risk-averse attitude regarding handicraft competencies and preservation of the Made in Italy culture may lead to loss of opportunities to support the growth of some mature sectors and to overcome the actual financial distress of many small and 
medium companies, which are nested in the industrial districts along with micro firms. This network of firms, especially in the Northern and Central part of the country, is likely to help achieve a balance between competition and cooperation. More pro-active measures to promote Chinese investments (attraction policy) are needed.

- The articles typically report post-acquisition facts and comments to integration issues. Due to cultural aspects, Chinese acquirers tend to be confidential in disclosing information after the acquisition takes place (Spigarelli et al., 2011) and are less open to communication to external stakeholders compared to other firms ${ }^{12}$. The cultural dimension high/low-context may help to explain the disclosure of information by the Chinese towards their in-group rather than towards the out-group members (external economic actors). This might result in less information provided to the press by the firm or other stakeholders such as trade unions and employees. It might be difficult for journalists to capture detailed information regarding the acquired companies and stakeholders' perceptions, especially from the employee perspective once the acquisition takes place (e.g., the case of Benelli in central Italy). This aspect might explain the reduced attention and interest to the employees. Their voices are typically more relevant during the pre-acquisition and negotiation phases and might be typically reported in newspapers or online daily journals, rather than in the examined periodicals. In the case of Italy, there is also another issue to take into account. The country's business system is rich with very small firms. Typically, those deals are reported and followed at local level by local newspapers. Magazines tend to mirror large acquisitions, which gain huge attention at national level.

- Next to the articles' analysis, the comments written by readers at the bottom of the web page can also be explored and may be considered as a suggestion for future research. Furthermore, they mirror the readers' opinion and not the view of the journalist. The authors of these comments do not typically represent any political party or interest groups (e.g., shareholders vs. employees). Conversely, the examined articles are written by journalists and may reflect certain political or interest groups' ideologies, which were not considered at this stage. This aspect should be taken into account since the stakeholders' opinion may contain this perception related "filter".

\footnotetext{
${ }^{12}$ Kao et al. (2014), with reference to Corporate Social Responsibility, noted that "contrary to the developed markets, the Chinese government plays a determinant role in CSR engagement of Chinese firms". Also, "contrary to the results of studies in the West, the government acts as a very important stakeholder in China and companies pay more attention to the interest of the government" (p. 54).
} 
- Suggestion for future research may consider a longitudinal content analysis of the national press articles in Italy and Germany over the last 5 years in order to detect how stakeholders' perceptions have changed over time. Follow up research may consider gathering more detailed information on pre- and post-acquisition, while focusing on both national and local magazines/newspapers. Screening all sources at national and local level should lead to a better representation of employee statements and perceptions. Local journalists also tend to be closer to local unions' associations.

\section{References:}

1. Abel-Koch, J., Del Bufalo, G., Fernandez, M., Gerstenberger, J., Lo, V., Navarro, B., \& Thornary, B. (2015). "SME investment and innovation", [online; October 2017]. Available from: https://www.kfw.de/PDF/Download-

Center/Konzernthemen/Research/PDF-Dokumente-Studien-undMaterialien/SME-Investment-and-Innovation-October-2015.pdf.

2. Arosio, P. \& Masoni, D. (2015). "ChemChina to buy into Italian tire maker Pirelli in $\$ 7.7$ billion deal", Reuters, [online; October 2017]. Available from: http://www.reuters.com/article/us-pirelli-chemchinaidUSKBNOMIOPQ20150323.

3. Arrighetti, A., Breda, E., Cappariello, R., Clemens, M., Ninni, A., \& Schumacher, D. (2012). Competitiveness in manufacturing. Germany vs. Italy - A Comparison, WP EPO1, pp. 1-64, [online; October 2017]. Available from: https://www.researchgate.net/profile/Emanuele_Breda/publication/24 1764906_Competitiveness_in_manufacturing_Germany_vs_Italy__a_comparison/links/0c960529618015a896000000/Competitivenessin-manufacturing-Germany-vs-Italy-a-comparison.pdf.

4. Aureli, S., Ciambotti, M., \& Salvatori, F. (2010). "Internationalisation of Italian shoemaking districts: some empirical evidence from the Marche region", Piccola Impresa/Small Business, Vol. 2, pp. 97-121.

5. Bellabona, P. \& Spigarelli, F. (2010). "Go Global e crisi mondiale. Sfide, insidie ed opportunità", Mondo Cinese, Vol. 143.

6. Bertelsmann, S. (2016). "Is China buying "Made in Germany"?", [online; October 2017]. Available from: https://www.bertelsmannstiftung.de/en/topics/aktuelle-meldungen/2016/november/is-chinabuying-made-in-germany/.

7. Buckley, P. J., Clegg, L. J., Cross, A. R., Liu, X., Voss, H., \& Zheng, P. (2007). "The determinants of Chinese outward foreign direct investment", Journal of international business studies, Vol. 38, No. 4, pp. 499-518. 
8. Burgoon, B. \& Raess, D. (2014). "Chinese investment and European labor: should and do workers fear Chinese FDI?", Asia Europe Journal, 2014, Vol. 12, No. 1, pp. 179-197.

9. Du, M. \& Boateng, A. (2015). "State ownership, institutional effects and value creation in cross-border mergers and acquisitions by Chinese firms", International Business Review, Vol. 24, pp. 430-442.

10. Fairclough, N. (1993). "Critical discourse analysis and the marketization of public discourse: The Universities. Discourse and Society", Vol. 4, No. 2, pp. 133-168.

11. Franke, R., Hofstede, G., \& Bond, M. H. (1991). "Cultural roots of economic performance: A research note", Strategic Management Journal, pp. 165-73.

12. Hanemann, T. \& Huotari, M. (2016). "A new record year for Chinese outbound investment in Europe", MERICS, Mercator Institute for China Studies, [online; October 2017]. Available from: http://www.merics.org/fileadmin/user_upload/downloads/COFDI_20 16/A_New_Record_Year_for_Chinese_Outbound_Investment_in_Eu rope.pdf.

13. Hanemann, T. \& Huotari, M. (2017). "Record flows and growing imbalances. Chinese investment in Europe in 2016", Papers on China, [online; October 2017]. Available from: http://rhg.com/wpcontent/uploads/2017/01/RHG_Merics_COFDI_EU_2016.pdf.

14. Hofmann, O. (1999). "Differences in international business cultures", [online; October 2017]. Available from: http://citeseerx.ist.psu.edu/viewdoc/download?doi=10.1.1.199.4248\& rep=rep1\&type $=$ pdf.

15. Hofstede, G. (2001). Cultural Consequences: Comparing Values, Behaviours, Institutions and Organizations Across Nations, 2nd Edition, Thousand Oaks CA: Sage Publications.

16. Hofstede, G. (2017). "Italy in comparison with China and Germany", [online; October 2017]. Available from: https://geerthofstede.com/italy.html.

17. Kao, E., Fung, H., \& Li, Q. (2014). "What Explains Corporate Social Responsibility Engagement in Chinese Firms?", Chinese Economy, Vol. 47, Nos. 5/6, pp. 50-80.

18. Klossek, A., Linke, B. M., \& Nippa, M. (2012). "Chinese enterprises in Germany: Establishment modes and strategies to mitigate the liability of foreignness", Journal of World Business, Vol. 47, No. 1, pp. 35-44.

19. Li, J., Li, P., \& Wang, B. (2016). "Do cross-border acquisitions create value? Evidence from overseas acquisitions by Chinese firms", International Business Review, Vol. 25, No. 2, pp. 471-483. 
20. Li, X., Huang, S. S., \& Song, C. (2017). "China's outward foreign direct investment in tourism", Tourism Management, Vol 59, pp. 1-6.

21. Liedtke, S. (2017). "Chinese energy investments in Europe: An analysis of policy drivers and approaches", Energy Policy, Vol. 101, pp. 659-669.

22. Ludovico, M. (2012). L'intelligence: Aziende sotto tiro dall'estero, Il Sole 24 Ore, [online; October 2017]. Available from: http://www.ilsole24ore.com/art/commenti-e-idee/2012-12-

07/lintelligence-aziende-sotto-tiro-064010.shtml?uuid=Abqc1t9G.

23. Mathews, J. A. (2006). "Dragon multinationals: New players in 21 st century globalization", Asia Pacific Journal of Management, Vol. 23, No. 1, pp. 5-27.

24. MERICS (2017). "Studie: Chinesische Investitionen in Europa erreichen neues Rekordniveau - Debatte über Risiken“, [online; October 2017]. Available from: http://www.presseportal.de/pm/114160/3531830.

25. Meunier, S., Burgoon, B., \& Jacoby, W. (2014). "The politics of hosting Chinese investment in Europe - an introduction”, Asia Europe Journal, Vol. 12, No. 1, pp. 109-126.

26. Morosini, P., Shane, S., \& Singh, H. (1998). "National cultural distance and crossborder acquisition performance", Journal of International Business Studies, Vol. 29, No. 1, pp. 137-158.

27. Moscarini, G. \& Postel-Vinay, F. (2012). "The contribution of large and small employers to job creation in times of high and low unemployment", American Economic Review, Vol. 102, No. 6, pp. 2509-39.

28. Mucelli, A., Micozzi, A., Rubens, A., \& Jackson, G. (2015). "A case study of Italy's Marche Region Industrial Districts: A model of transformation and change", Journal of Business Cases and Applications, Vol. 13, pp. 1-23, [online; October 2017]. Available from: http://www.aabri.com/manuscripts/142092.pdf.

29. Mueller, K., Hattrup, K., Spiess, S-O., \& Lin-Hi, N. (2012). "The effects of corporate social responsibility on employees' affective commitment: A cross-cultural investigation", Journal of Applied Psychology, Vol. 97, No. 6, pp. 1186-1200.

30. Pareja-Alcaraz, P. (2017). "Chinese investments in Southern Europe's energy sectors: Similarities and divergences in China's strategies in Greece, Italy, Portugal and Spain”, Energy Policy, Vol. 101, pp. 700710.

31. Pickens, J. (2005). Attitudes and perceptions, in N. Borkowski (Ed.), Organizational behaviour in health care, USA, Jones and Barlett Publishers, pp. 43-76. 
32. Quintanilla, J. (2000). National business environments: A proposed framework, Research Paper No. 417, IESE Business School, [online; October 2017]. Available from: http://www.iese.edu/research/pdfs/DI0417-E.pdf.

33. Ramasamy, B., Yeung, M., \& Laforet, S. (2012). "China's outward foreign direct investment: Location choice and firm ownership", Journal of World Business, Vol. 47, No. 1, pp. 17-25.

34. Ricciardi, R. (2016). La Cina investe 20 miliardi in Europa. Ecco perché sceglie il Made in Italy, La Repubblica, [online; October 2017]. Available from: http://www.repubblica.it/economia/2016/07/24/news/la_cina_investe _20_miliardi_nel_belpaese_ecco_cosa_cerca_nel_made_in_italy144690712/.

35. Rhodium Group (2016). China [online; October 2017]. Available from: http://rhg.com/topics/china.

36. Rhodium Group (2017). China [online; October 2017]. Available from: http://rhg.com/topics/china.

37. Sinclair, J. \& Coulthard, R. M. (1975). Toward an Analysis of Discourse, Oxford, Oxford University Press.

38. Shenkar, O. (2012). "Beyond cultural distance: Switching to a friction lens in the study of cultural differences", Journal of International Business Studies, Vol. 43, No. 1, pp. 12-17.

39. Spigarelli, F. (2009). "Le multinazionali dei paesi emergent: Gli investimenti cinesi in Italia", Economia Politica e Industriale, Vol. 2, pp. 131-159.

40. Spigarelli, F., Alon, I., \& Wei, W. (2008). "Speed race: Benelli and Qj compete in the international motorbike arena", in Alon, I, Fetscherin, $\mathrm{M}$ and $\mathrm{P}$. Gugler (eds), Chinese International Investments, Palgrave Macmillan, 2011.

41. Spigarelli, F., Alon, I., \& Mucelli, A. (2013). "Chinese overseas M\&A: overcoming cultural and organisational divides", Int. J. Technological Learning, Innovation and Development, Vol. 6, Nos. 1/2, pp.190-208.

42. Sviluppo Economico (2017). "German-Italian cooperation on Industry 4.0", [online; October 2017]. Available from: http://www.sviluppoeconomico.gov.it/images/stories/documenti/ger man-italian_cooperation_on\%20i40.pdf.

43. Tao, F., Liu, X., Gao, L., \& Xia, E. (2017). "Do cross-border mergers and acquisitions increase short-term market performance? The case of Chinese firms", International Business Review, Vol. 26, No. 1, pp. 189-202.

44. The World Bank (2017a). Germany [online; October 2017]. Available from: http://data.worldbank.org/country/germany. 
45. The World Bank (2017b). Italy [online; October 2017]. Available from: http://data.worldbank.org/country/italy.

46. Turano, G. (2016). Shopping alla cinese, L'Espresso [online; October 2017].

Available from: http://espresso.repubblica.it/attualita/2016/07/25/news/calcioshopping-alla-cinese-1.278435.

47. Trompenaars, F. (1993). Riding the waves of culture, Burr Ridge, IL: Irwin.

48. UNCTAD (2016). World Investment Report, [online; October 2017]. Available from: http://unctad.org/en/PublicationsLibrary/wir2016_en.pdf.

49. Vaara, E., Sarala, R., Stahl, G., \& Bjorkman, I. (2012). "The impact of organizational and national cultural differences on social conflict and knowledge", Journal of Management Studies, Vol. 49, No. 1, pp. 127.

50. Vaccarini, K., Lattemann, C., Spigarelli, F., \& Tavoletti, E. (2017). "Chinese FDI and psychic distance perceptions on regulations in the German renewable energy sector", Energy Policy, Vol. 101, pp. 723732.

51. Van Dijk, T. A. (2000). Ideology and Discourse A Multidisciplinary Introduction, Pompeu Fabra University, Barcelona.

52. Whitley, R. (1999). Divergent Capitalism: The Social Structuring and Change of Business Systems, Oxford: Oxford University press.

53. Whitley, R. (2001). How and Why are International Firms Different?, pp. 27-68, in Glenn Morgan, Peer Hull Kristensen and Richard Whitley (eds.) The Multinational Firm, Oxford: Oxford University Press.

54. Whitley, R. (2010). "The Institutional Construction of Firms," in The Oxford Handbook of Comparative Institutional Analysis, Glenn Morgan, John Campbell, Colin Crouch, Ove Kaj Pedersen, and Richard Whitley (Eds.). Oxford: Oxford University Press, pp. 453495.

55. Wübbeke, J., Meissner, M., Zenglein, M. J., Ives, J., \& Conrad, B. (2016). Made in China 2025. The making of a high-tech superpower and consequences for industrial countries", Papers on China, No. 2, MERICS, Mercator Institute for China Studies [online; October 2017]. Available from: http://www.iberchina.org/files/2016/MadeinChina_2025_merics.pdf. 